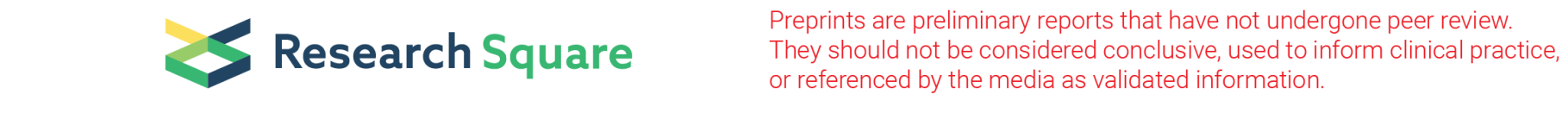

\title{
OSA-induced multi-organ dysfunction after elective coronary artery bypass surgery in coronary heart disease patients
}

\author{
Jiayang Wang ( $\nabla$ athlandwang@hotmail.com ) \\ Capital Medical University Affiliated Anzhen Hospital \\ Xinxin Wang \\ Chinese PLA General Hospital \\ Wenyuan Yu \\ Capital Medical University Affiliated Anzhen Hospital \\ Kui Zhang \\ Capital Medical University Affiliated Anzhen Hospital \\ Yongxiang Wei \\ Capital Medical University Affiliated Anzhen Hospital
}

\section{Research}

Keywords: Obstructive sleep apnea, Coronary heart disease, Elective coronary artery bypass grafting, Postoperative multi-organ dysfunction

Posted Date: February 11th, 2020

DOI: https://doi.org/10.21203/rs.2.23154/v1

License: (c) (1) This work is licensed under a Creative Commons Attribution 4.0 International License. Read Full License 


\section{Abstract}

Background The aim of this study was to explore the underlying impact of obstructive sleep apnea (OSA) on postoperative parameters of multiorgan function, including cardiac and cerebral vascular, respiratory as well as renal postoperative complications, among coronary heart disease (CHD) patients following elective coronary artery bypass grafting (CABG).

Methods Electronic literature databases, including PubMed, ISI Web of Science, Directory of Open Access Journals, and the Cochrane Library electronic databases, were searched manually and automatically for relevant English articles. All of the selected articles focused on a comparison of the incidence of primary and secondary outcomes in CHD patients undergoing elective CABG with and without OSA.

Results A total of 13 articles met our inclusion criteria. The current study demonstrated OSA significantly increased the incidence of major adverse cardiac and cerebrovascular events (MACCEs) in CHD patients undergoing elective CABG compared with the controls (odds risk (OR), 1.97; 95\% confidence interval $(\mathrm{Cl}), 1.50$ to $2.59, \mathrm{p}<0.0001)$. In addition, OSA was associated with an increased risk of new revascularization in CHD patients undergoing elective $\mathrm{CABG}(\mathrm{OR}, 9.47 ; 95 \% \mathrm{Cl}, 2.69$ to $33.33, \mathrm{p}<0.0001)$. Moreover, reintubation and tracheostomy in the OSA group was increased (OR, 3.43; $95 \% \mathrm{Cl}, 1.35$ to $8.71 ; \mathrm{p}=0.009)$ and $372 \%(\mathrm{OR}, 4.72 ; 95 \% \mathrm{Cl}, 1.23$ to $18.13 ; \mathrm{p}=0.024)$, respectively, compared with the control group. Besides, we also confirmed OSA significantly increased the acute kidney injury (AKI) incidence by $124 \%(\mathrm{OR}, 2.24 ; 95 \% \mathrm{Cl}, 1.07$ to $4.72 ; \mathrm{P}<0.0001)$. Finally, our results demonstrated that OSA increased medical resource utilization including length of postoperative hospital stay and ICU stay.

Conclusions OSA may contribute to postoperative multi-organ dysfunction among CHD patients undergoing elective CABG by increasing the incidence of MACCEs, especially new revascularization, as well as respiratory, and renal complications. Peri- and postoperative management of CHD patients with OSA may be optimized to minimize the rate of postoperative parameters of multi-organ dysfunction, further reducing the consumption of limited medical resources.

\section{Background}

Obstructive sleep apnea (OSA), a syndrome caused by repeated narrowing of the throat during sleep, is a common breathing-associated sleep disorder with recent estimates of prevalence in the general adult population ranging from 9 to $38 \%{ }^{1,2}$ In coronary heart disease (CHD) patients undergoing elective coronary artery bypass grafting $(\mathrm{CABG})$, the incidence of mild OSA ( $5 \leq$ apnea- hypopnea index $[A H I]<15)$ and moderate to severe OSA (AHI $\geq 15$ ) is $74 \%$ and $48 \%$, respectively. ${ }^{3}$ Despite the high prevalence of OSA among CHD patients following CABG, the impact of OSA in the postoperative multi-organ function is not well established. Most of the evidence is focused on arrhythmia recurrence after cardiac surgery, 4,5 the effects of OSA on respiratory as well as renal parameters still need to be investigated further. In addition, as for the cardio-cerebrovascular complications, recent studies are based on patients diagnosed with different cardiac diseases undergoing various types of elective cardiac surgeries. ${ }^{6-8}$ Data on CHD patients developing postoperative complications after CABG are sparse. As far as now, no meta-analyses have focused on documenting a direct correlation between CHD patients following elective CABG with OSA and higher risk of adverse cardiac and cerebral vascular events.

This current meta-analysis was initiated to fill the above knowledge gaps. We particularly focused on CHD patients with or without OSA. The aim of this study was to explore the underlying impact of OSA on postoperative parameters of multi-organ function, including cardiac and cerebral vascular, respiratory as well as renal postoperative complications, among CHD patients following elective CABG. Recognition of the association and determinants of OSA on postoperative multiple organ dysfunction should lead to strategies to improve the prognosis of CHD patients undergoing elective CABG.

\section{Methods}

\section{Literature search and selection criteria}

This systematic review and meta-analysis were conducted and reported in adherence to the Preferred Reporting Items for Systematic Reviews and Meta-Analyses (PRISMA) guidelines. ${ }^{9}$ Electronic literature databases, including PubMed, ISI Web of Science, Directory of Open Access Journals, and the Cochrane Library electronic databases, were searched manually and automatically for relevant English articles. All of the selected articles focused on a comparison of the incidence of primary and secondary outcomes in CHD patients undergoing elective CABG with and without OSA.

As for further full-text assessment. The references of the retrieved articles were also reviewed to identify additional eligible studies. The study selection program was shown in Figure i online. Studies meeting the following criteria were included:

The following search terms were used: ("sleep apnea" [All Fields] OR "sleep apnea" [All Fields]) AND ("CABG" [All Fields] OR "coronary artery bypass grafting" [All Fields]) AND ("major adverse cardiac and cerebrovascular events" [All Fields] OR "cardiovascular outcomes" [All Fields] OR "major cardiovascular and cerebrovascular adverse events" [All Fields]). 
The last search was conducted on July 1, 2019 Two investigators (J.W. and W.Y.) performed the initial search separately, deleted duplicate records, screened titles and abstracts for relevance, and identified relevant article

1. Patients: subjects were $\mathrm{CHD}$ patients following elective $\mathrm{CABG}$.

2. Intervention: elective CABG.

3. Comparison: $\mathrm{CHD}$ patients undergoing elective CABG with preoperative OSA vs. CHD patients undergoing elective CABG without preoperative OSA.

4. Outcomes: multi-organ parameters, including cardiac, respiratory and renal parameters; in-hospital death; infection; intensive care unit (ICU)readmission; length of ICU stay; length of hospital stay.

5. Study design: observational studies (prospective or retrospective cohort studies) were included in this meta-analysis.

\section{Data Extraction and Quality Assessment}

Two reviewers (J.W. and W.Y.) independently extracted the following information from the eligible studies: first author, year of publication, country, study design, patient characteristics, number of patients enrolled, intervention, and outcome data. When the same patients were reported in several publications, only the largest study was retained to avoid duplication of information. The current study used the Downs and Black score system to evaluate the quality of each study. The quality of studies with a score $\geq 20$ was considered good and a score $<20$ was considered poor.

\section{Study End Points and OSA Definition}

The AHI was defined as the average number of episodes of apneas and hypopneas per hour of sleep. OSA must be diagnosed by polysomnography (PSG), which was defined in events per hour as AHI $\geq 5$ or screened as "high-risk OSA" by screening questionnaire.

Diagnosis of OSA and pre-/postoperative continuous positive airway pressure (CPAP) use in patients with OSA were shown in Table 1. Endpoints were as follows: 1. A composite end point of major adverse cardiac and cerebrovascular events (MACCEs) up to 30 days after surgery, including: cardiac death, myocardial infarction (MI), myocardial injury, nonfatal cardiac arrest, new revascularization (PCI or CABG), pulmonary embolism, deep venous thrombosis, newly documented postoperative atrial fibrillation (POAF), postoperative cerebral vascular accident (CVA) or transient ischemic attack (TIA), and congestive heart failure. MACCEs and variables of major morbidity defined as in the Society of Thoracic Surgeons (STS) national database.$^{10}$ 2. Acute respiratory distress syndrome (ARDS), pneumonia, or pulmonary embolism represented major pulmonary complications.

\section{Statistical Analysis}

Differences are expressed as odds risk (OR) or standardized mean difference (SMD) with 95\% confidence interval (CI). Study heterogeneity was tested using the $\mathrm{I}^{2}$ statistic. Heterogeneity was considered to be low in studies with an $\mathrm{I}^{2}$ between $25 \%$ and $50 \%$, moderate in studies with an $\mathrm{I}^{2}$ between $50 \%$ and $75 \%$, and high in studies with an $\mathrm{I}^{2}$ exceeding $75 \%$. $\mathrm{I}^{2}$ exceeding $50 \%$ represents significant heterogeneity. A fixed-effects model was used when study heterogeneity was not significant; a random effects model was used when study heterogeneity was significant. Funnel plots and the Egger linear regression test were used to estimate publication bias. Meta-regression analysis was performed to examine whether the pooled outcomes could be modified by the confounding factor. A Q model statistic was used in the meta-regression. All $p$ values are two-sided. Statistical analyses were conducted by using Stata 15.0 software (StataCorp LP, College Station, TX).

\section{Results}

\section{Study Selection, Characteristics and Quality Assessment}

The selection process is illustrated in Fig. i online. A total of 13 articles met our inclusion criteria. $3,11-22$ The main characteristics of the included studies are described in Table 2. Total primary and secondary pooled outcomes in patients with and without OSA were demonstrated in Table 3. Of the 13 reports, three contained CHD patients following elective CABG + valvular surgery. ${ }^{3,12,19}$ Meta-regression analysis was performed to examine whether the above pooled outcomes could be modified by the valvular surgery. The results were shown in Table 3 . In addition, Downs and Black Score analysis revealed that all of the 13 articles had good quality (score $\geq 20$, Table 2). 
Table 2

Patient characteristics and down and black scores

\begin{tabular}{|c|c|c|c|c|c|c|c|c|}
\hline \multirow[t]{2}{*}{ Reference } & \multirow[t]{2}{*}{ Setting } & \multirow[t]{2}{*}{$\begin{array}{l}\text { Selective } \\
\text { CABG Surgery }\end{array}$} & $\begin{array}{l}\text { Patients, } \\
\text { No. }\end{array}$ & $\begin{array}{l}\text { Mean } \\
\text { Age, y }\end{array}$ & Male, \% & \multirow{2}{*}{$\begin{array}{l}\text { Reported } \\
\text { organ } \\
\text { outcomes }\end{array}$} & \multirow[t]{2}{*}{$\begin{array}{l}\text { Downs and } \\
\text { Black score }\end{array}$} & \multirow[t]{2}{*}{$\begin{array}{l}\text { The severity } \\
\text { of OSA }\end{array}$} \\
\hline & & & \multicolumn{3}{|c|}{ CABG-OSAVControl } & & & \\
\hline Mooe et al & $\begin{array}{l}\text { OB, } \\
\text { Single center } \\
\text { (Sweden) }\end{array}$ & CABG alone & $78 / 39$ & $62 / 61.3$ & NR & Cardiac & 22 & $\begin{array}{l}\text { Mild, moderate } \\
\text { and severe OSA }\end{array}$ \\
\hline KAW et al & $\begin{array}{l}\text { OB } \\
\text { Single center } \\
\text { (United } \\
\text { States) }\end{array}$ & $\mathrm{CABG} \pm$ Valve & $29 / 146$ & $62 / 61$ & $78 / 77$ & $\begin{array}{l}\text { Cardiac, } \\
\text { Renal, } \\
\text { Pulmonary }\end{array}$ & 21 & $\begin{array}{l}\text { Mild, moderate } \\
\text { and severe OSA }\end{array}$ \\
\hline Bhama et al & $\begin{array}{l}\text { OB } \\
\text { Single center } \\
\text { (United } \\
\text { States) }\end{array}$ & CABG alone & $20 / 65$ & $65 / 65$ & $100 / 100$ & $\begin{array}{l}\text { Cardiac, } \\
\text { Pulmonary }\end{array}$ & 20 & $\begin{array}{l}\text { Mild, moderate } \\
\text { and severe OSA }\end{array}$ \\
\hline Sharma et al & $\begin{array}{l}\text { OB } \\
\text { Single center } \\
\text { (United } \\
\text { States) }\end{array}$ & CABG alone & $81 / 40$ & $60 / 59$ & $69 / 31$ & $\begin{array}{l}\text { Cardiac, } \\
\text { Pulmonary }\end{array}$ & 21 & $\begin{array}{l}\text { Mild, moderate } \\
\text { and severe OSA }\end{array}$ \\
\hline Mungan et al & $\begin{array}{l}\text { OB } \\
\text { Single center } \\
\text { (Turkey) }\end{array}$ & CABG alone & $33 / 40$ & NR & NR & Cardiac & 20 & $\begin{array}{l}\text { Mild, moderate } \\
\text { and severe OSA }\end{array}$ \\
\hline Amra et al & $\begin{array}{l}\text { OB } \\
\text { Single center } \\
\text { (Iran) }\end{array}$ & CABG alone & $25 / 36$ & $61.1 / 57.3$ & $72 / 83$ & $\begin{array}{l}\text { Cardiac, } \\
\text { Pulmonary }\end{array}$ & 23 & $\begin{array}{l}\text { Mild, moderate } \\
\text { and severe OSA }\end{array}$ \\
\hline Oosten et al & $\begin{array}{l}\text { OB } \\
\text { Single center } \\
\text { (Canada) }\end{array}$ & CABG alone & $132 / 145$ & $63 / 66$ & $80 / 76$ & $\begin{array}{l}\text { Cardiac, } \\
\text { Pulmonary }\end{array}$ & 24 & $\begin{array}{l}\text { Mild, moderate } \\
\text { and severe OSA }\end{array}$ \\
\hline Wong et al & $\begin{array}{l}\text { OB } \\
\text { Single center } \\
\text { (United } \\
\text { States) }\end{array}$ & CABG alone & $26 / 195$ & $67 / 65$ & $79 / 66$ & $\begin{array}{l}\text { Cardiac, } \\
\text { Renal, } \\
\text { Pulmonary }\end{array}$ & 22 & $\begin{array}{l}\text { Mild, moderate } \\
\text { and severe OSA }\end{array}$ \\
\hline $\begin{array}{l}\text { Foldvary- } \\
\text { schaeler et al }\end{array}$ & $\begin{array}{l}\text { OB } \\
\text { Single center } \\
\text { (United } \\
\text { States) }\end{array}$ & $\mathrm{CABG} \pm$ Valve & $45 / 28$ & NR & NR & $\begin{array}{l}\text { Cardiac, } \\
\text { Pulmonary }\end{array}$ & 21 & $\begin{array}{l}\text { Moderate and } \\
\text { severe OSA }\end{array}$ \\
\hline Zhao et al & $\begin{array}{l}\text { OB } \\
\text { Single center } \\
\text { (Singapore) }\end{array}$ & CABG alone & $128 / 32$ & $61 / 63$ & $86 / 81$ & $\begin{array}{l}\text { Cardiac, } \\
\text { Renal }\end{array}$ & 21 & $\begin{array}{l}\text { Mild, moderate } \\
\text { and severe OSA }\end{array}$ \\
\hline Uchoa et al & $\begin{array}{l}\text { OB } \\
\text { Single center } \\
\text { (Brazil) }\end{array}$ & CABG alone & $37 / 30$ & $59 / 55$ & $84 / 63$ & $\begin{array}{l}\text { Cardiac, } \\
\text { Pulmonary }\end{array}$ & 25 & $\begin{array}{l}\text { Moderate and } \\
\text { severe OSA }\end{array}$ \\
\hline Patel et al & $\begin{array}{l}\text { OB } \\
\text { Single center } \\
\text { (United } \\
\text { States) }\end{array}$ & $\mathrm{CABG} \pm$ Valve & $31 / 178$ & NR & $67.7 / 74.1$ & $\begin{array}{l}\text { Cardiac, } \\
\text { Pulmonary }\end{array}$ & 22 & $\begin{array}{l}\text { Mild, moderate } \\
\text { and severe OSA }\end{array}$ \\
\hline $\begin{array}{l}\text { Tafelmeier } \\
\text { et al }\end{array}$ & $\begin{array}{l}\text { OB } \\
\text { Single center } \\
\text { (Germany) }\end{array}$ & CABG alone & $23 / 77$ & $72 / 67$ & $91 / 82$ & $\begin{array}{l}\text { Cardiac, } \\
\text { Renal, } \\
\text { Pulmonary }\end{array}$ & 23 & $\begin{array}{l}\text { Moderate and } \\
\text { severe OSA }\end{array}$ \\
\hline
\end{tabular}


Table 3

Total Primary and Secondary Pooled Outcomes in Patients with and without OSA and Meta-regression Examining Whether the Above Pooled Outcomes Could be Modified by the Confounding Factor

\begin{tabular}{|c|c|c|c|c|c|c|c|c|c|}
\hline \multirow[t]{4}{*}{ Outcomes } & \multicolumn{2}{|c|}{ Sample size } & \multirow{4}{*}{$\begin{array}{l}\text { NO. of } \\
\text { included } \\
\text { references }\end{array}$} & \multirow{4}{*}{$\begin{array}{l}\text { Heterogeneity } \\
\mathrm{I}^{2}(\%)\end{array}$} & \multirow{4}{*}{$\begin{array}{l}\text { Pooled } \\
\text { OR/ } \\
\text { SMD }\end{array}$} & \multirow{4}{*}{$\begin{array}{l}95 \% \\
\mathrm{Cl}\end{array}$} & \multirow{4}{*}{$\begin{array}{l}\mathrm{P}- \\
\text { value }\end{array}$} & \multirow{4}{*}{$\begin{array}{l}\text { Selective } \\
\text { CABG } \\
\text { Surgery }\end{array}$} & \multirow{4}{*}{$\begin{array}{l}\text { Confounding factor: } \\
\text { CABG + Valve }\end{array}$} \\
\hline & CABG- & No & & & & & & & \\
\hline & OSA & CABG- & & & & & & & \\
\hline & & OSA & & & & & & & \\
\hline \multicolumn{10}{|l|}{$\begin{array}{l}\text { Primary } \\
\text { outcomes }\end{array}$} \\
\hline \multicolumn{10}{|l|}{$\begin{array}{l}\text { Postoperative } \\
\text { cardiac } \\
\text { and } \\
\text { cerebrovascular } \\
\text { parameters }\end{array}$} \\
\hline $\begin{array}{l}\text { MACCEs, n (\%) * } \\
\text { Post-MI, n (\%) } \\
\text { Post-TIA or CVA, } \\
\text { n (\%) } \\
\text { New } \\
\text { revascularization, } \\
\text { PCl/CABG, n (\%) } \\
\text { * }\end{array}$ & $\begin{array}{l}209 / 688 \\
10 / 105 \\
8 / 236 \\
15 / 60\end{array}$ & $\begin{array}{l}145 / 1051 \\
22 / 135 \\
5 / 285 \\
4 / 107\end{array}$ & $\begin{array}{l}13 \\
3 \\
4 \\
2\end{array}$ & $\begin{array}{l}9.3 \\
0.0 \\
0.0 \\
0.0\end{array}$ & $\begin{array}{l}1.97 \\
1.30 \\
2.24 \\
9.47\end{array}$ & $\begin{array}{l}1.50- \\
2.59 \\
0.53- \\
3.17 \\
0.64- \\
7.89 \\
2.69- \\
33.33\end{array}$ & $\begin{array}{l}< \\
0.0001 \\
0.571 \\
0.653 \\
< \\
0.0001\end{array}$ & $\begin{array}{l}\text { CABG } \pm \\
\text { Valve } \\
\text { CABG } \pm \\
\text { Valve } \\
\text { CABG } \pm \\
\text { Valve } \\
\text { CABG } \\
\text { alone }\end{array}$ & $\begin{array}{l}0.20(-0.69,1.09) / 0.665 \\
-0.84(-3.80,2.13) / 0.581 \\
-1.02(-3.57,1.51) / 0.427 \\
\text { None }\end{array}$ \\
\hline \multicolumn{10}{|l|}{$\begin{array}{l}\text { Secondary } \\
\text { outcomes }\end{array}$} \\
\hline \multicolumn{10}{|l|}{$\begin{array}{l}\text { Postoperative } \\
\text { respiratory } \\
\text { parameters }\end{array}$} \\
\hline $\begin{array}{l}\text { Major pulmonary } \\
\text { complications, } \mathrm{n} \\
(\%)\end{array}$ & $22 / 134$ & $32 / 281$ & 4 & 0.0 & 1.19 & $\begin{array}{l}0.62- \\
2.30\end{array}$ & 0.603 & $\begin{array}{l}\text { CABG } \pm \\
\text { Valve }\end{array}$ & $-0.84(-0.22,0.51) / 0.224$ \\
\hline $\begin{array}{l}\text { Reintubation, } \mathrm{n} \\
(\%) \text { * }\end{array}$ & $40 / 383$ & $27 / 765$ & 8 & 50.0 & 3.43 & $\begin{array}{l}1.35- \\
9.71\end{array}$ & 0.009 & $\begin{array}{l}\text { CABG } \pm \\
\text { Valve }\end{array}$ & $-1.51(-3.03,0.01) / 0.051$ \\
\hline $\begin{array}{l}\text { Tracheostomy, n } \\
(\%) \text { * }\end{array}$ & $7 / 94$ & $4 / 300$ & 3 & 0.0 & 4.72 & $\begin{array}{l}1.23- \\
18.13\end{array}$ & 0.024 & $\begin{array}{l}\text { CABG } \pm \\
\text { Valve }\end{array}$ & $-1.39(-4.14,1.46) / 0.349$ \\
\hline $\begin{array}{l}\text { Pulmonary } \\
\text { edema, n (\%) }\end{array}$ & $22 / 60$ & $66 / 107$ & 2 & 0.0 & 1.48 & $\begin{array}{l}0.43- \\
5.08\end{array}$ & 0.536 & $\begin{array}{l}\text { CABG } \\
\text { alone }\end{array}$ & None \\
\hline \multicolumn{10}{|l|}{$\begin{array}{l}\text { Postoperative } \\
\text { renal parameters }\end{array}$} \\
\hline $\mathrm{AKI}, \mathrm{n}(\%)$ * & $18 / / 205$ & $35 / 450$ & 4 & 0.0 & 2.24 & $\begin{array}{l}1.07- \\
4.72\end{array}$ & 0.033 & $\begin{array}{l}\text { CABG } \pm \\
\text { Valve }\end{array}$ & $-0.72(-3.08 .1 .64) / 0.551$ \\
\hline \multicolumn{10}{|l|}{$\begin{array}{l}\text { Exploratory } \\
\text { parameters }\end{array}$} \\
\hline $\begin{array}{l}\text { In-hospital death, } \\
\text { n (\%) }\end{array}$ & $9 / 316$ & $13 / 675$ & 7 & 0.0 & 1.62 & $\begin{array}{l}0.64- \\
4.07\end{array}$ & 0.307 & $\begin{array}{l}\text { CABG } \pm \\
\text { Valve }\end{array}$ & $-0.63(-2.53,1.28) / 0.518$ \\
\hline Infection, n (\%) & $16 / 203$ & $14 / 315$ & 5 & 0.0 & 1.24 & $\begin{array}{l}0.57- \\
2.71\end{array}$ & 0.591 & $\begin{array}{l}\text { CABG } \pm \\
\text { Valve }\end{array}$ & $0.29(-1.83,2.41) / 0.788$ \\
\hline ICU-readmission & $2 / 25$ & $3 / 36$ & 3 & 0.0 & 1.68 & $\begin{array}{l}0.67- \\
4.20\end{array}$ & 0.264 & $\begin{array}{l}\text { CABG } \pm \\
\text { Valve }\end{array}$ & $0.37(-1.49,2.23) / 0.696$ \\
\hline $\begin{array}{l}\text { Length of ICU } \\
\text { stay }\end{array}$ & $\mathrm{NE}$ & $\mathrm{NE}$ & 6 & 30.6 & $\begin{array}{l}0.30 \\
\text { (SMD) }\end{array}$ & $\begin{array}{l}0.12- \\
0.47\end{array}$ & $<.0001$ & $\begin{array}{l}\text { CABG } \pm \\
\text { Valve }\end{array}$ & $-0.02(-1.84,1.80) / 0.982$ \\
\hline $\begin{array}{l}\text { Length of } \\
\text { hospital stay }\end{array}$ & $\mathrm{NE}$ & $\mathrm{NE}$ & 7 & 20.8 & $\begin{array}{l}0.30 \\
\text { (SMD) }\end{array}$ & $\begin{array}{l}0.16- \\
0.44\end{array}$ & $<.0001$ & $\begin{array}{l}\text { CABG } \pm \\
\text { Valve }\end{array}$ & $1.25(-1.67,4.17) / 0.402$ \\
\hline
\end{tabular}




\section{The impact of OSA on postoperative multi-organ function in CHD patients following elective CABG}

\section{Postoperative cardiac and cerebrovascular parameters}

The current study demonstrated OSA significantly increased the incidence of MACCEs in CHD patients undergoing elective CABG compared with the controls (OR, 1.97; $95 \% \mathrm{Cl}, 1.50$ to 2.59, $\mathrm{p}<0.0001$; Fig. $1 \mathrm{~A}$ and Table 3 ) without significant heterogeneity $\left(\mathrm{I}^{2}=9.3 \%\right)$ and publication bias $(\mathrm{p}=$ 876). The funnel plot also showed low publication bias (Fig. ii online). No significant effects were detected in meta-regression analysis with respect to the examined covariate ( $p=0.665$ Table 3$)$; namely, the valvular surgery. In addition, OSA was associated with an increased risk of new revascularization, including $\mathrm{CABG}$ and percutaneous coronary intervention (PCI), in $\mathrm{CHD}$ patients undergoing elective $\mathrm{CABG}(\mathrm{OR}, 9.47$; $95 \% \mathrm{Cl}, 2.69$ to 33.33, $p<0.0001$; Fig. 1D and Table 3 ) without significant heterogeneity $\left(I^{2}=0.0 \%\right)$. Since all the included patients in this endpoint underwent $\mathrm{CABG}$ alone, the confounding factor had no effects on the pooled outcome. Furthermore, the current meta-analysis confirmed OSA did not affect the incidence of postoperative MI and CVA or TIA (Fig. 1B, 1C and Table 3).

\section{Postoperative respiratory parameters}

The current study demonstrated that reintubation in the OSA group was increased by $243 \%$ compared with the control group (OR, 3.43 ; $95 \%$ Cl, 1.35 to $8.71 ; p=0.009$; Fig. $2 \mathrm{~B}$ and Table 3$)$ but with significant heterogeneity $\left(\mathrm{I}^{2}=50.0 \%\right)$. Meanwhile, patients with 0 SA group showed a $372 \%$ increase in tracheostomy compared with the control group (OR, 4.72; $95 \% \mathrm{Cl}, 1.23$ to $18.13 ; \mathrm{p}=0.024$; Fig. $2 \mathrm{C}$ and Table 3 ) without significant study heterogeneity $\left(I^{2}=0.0 \%\right)$. Furthermore, we found OSA did not affect the incidence of postoperative major pulmonary complications and pulmonary edema (Fig. 2A, 2D and Table 3). In meta-regression analysis, we found the examined covariate, namely, the valvular surgery, had no significant effect on the above pooled outcomes.

\section{Postoperative renal parameters}

We also confirmed OSA significantly increased the AKI incidence by $124 \%$ (OR, 2.24; $95 \% \mathrm{Cl}, 1.07$ to 4.72 ; P $<0.0001$; Fig. 3 and Table 3 ) without significant study heterogeneity $\left(I^{2}=0.0 \%\right)$. In meta-regression analysis, we found the examined covariate, namely, the valvular surgery, had no significant effect on the above pooled outcomes.

\section{The impact of OSA on postoperative exploratory parameters in CHD patients undergoing elective CABG}

Our results demonstrated that OSA increased medical resource utilization including length of postoperative hospital stay (SMD, $0.30 ; 95 \% \mathrm{Cl}, 0.12$ to 0.47 ; $<$ 0.0001; Table 3) and ICU stay (SMD, 0.30; $95 \% \mathrm{Cl}, 0.16$ to $0.44 ; \mathrm{p}<0.0001$; Table 3) without significant study heterogeneity. On the contrary, OSA did not affect the incidence of postoperative in-hospital death, infection and ICU-readmission (Table 3). In meta-regression analysis, we found the examined covariate, namely, the valvular surgery, had no significant effect on the above pooled outcomes.

Meta-regression Analysis of the Potential Modifiers

Meta-regression analysis demonstrated the above pooled outcomes could not be modified by the valvular surgery (Table 3). Furthermore, the results also shown the above pooled outcomes were not affected by the following modifiers, including confirmation of OSA (PSG or not); quality of study; loss of patients due to follow-up and OSA with CPAP treatment (Table 4).

Table 4

Meta-regression for OSA and Postoperative Composite Outcomes

\begin{tabular}{|c|c|c|c|c|c|c|c|c|}
\hline \multirow[t]{2}{*}{ Meta-regression Variables } & \multicolumn{2}{|c|}{ MACCEs } & \multicolumn{2}{|c|}{ Major pulmonary complications } & \multicolumn{2}{|c|}{ Reintubation } & \multicolumn{2}{|l|}{ AKI } \\
\hline & Exp (b) & P Value & Exp (b) & P Value & $\operatorname{Exp}(b)$ & P Value & $\operatorname{Exp}(b)$ & P Value \\
\hline Confirmation of OSA (PSG or not) & 0.876 & 0.359 & 0.375 & 0.578 & 0.724 & 0.772 & 0.818 & 0.904 \\
\hline Quality of study & 0.517 & 0.479 & 1.047 & 0.126 & 1.004 & 0.379 & 0.725 & 0.884 \\
\hline $\begin{array}{l}\text { Loss of patients } \\
\text { due to follow-up }\end{array}$ & 0.997 & 0.871 & NE & $\mathrm{NE}$ & 1.475 & 0.127 & $\mathrm{NE}$ & $\mathrm{NE}$ \\
\hline OSA with CPAP treatment & 0.224 & 0.529 & 1.035 & 0.810 & 0.780 & 0.325 & 1.156 & 0.587 \\
\hline
\end{tabular}




\section{Discussion}

To the best of our knowledge, this is the first meta-analysis to comprehensively examine the association between OSA and postoperative multiorgan dysfunction in CHD patients undergoing elective CABG. Our key findings are: 1) compared with the control group, OSA significantly increased the incidence of MACCEs in CHD patients undergoing elective CABG. In addition, OSA was associated with an increased risk of new revascularization, including $C A B G$ and $P C I$, in $C H D$ patients undergoing elective CABG; 2) reintubation in the OSA group was increased compared with the control group. Meanwhile, patients with OSA group showed an increase in tracheostomy compared with the control group; 3) OSA significantly increased the AKI incidence compared with the control group; 4) we also confirmed the association between OSA and increased medical resource utilization. Meta-regression showed the examined covariates had no significant effect on the above pooled outcomes.

In the past 10 years, only one meta-analysis had investigated the effects of preoperative OSA on postoperative MACCEs among patients following cardiac surgery. ${ }^{6}$ However, the heterogeneity of the results cannot be ignored $\left(1^{2}=64 \%\right)$. Previous meta-analysis focused on patients with varying cardiovascular diseases, including CHD, valvular heart disease and aortic disease, which might account for the source of the huge heterogeneity and led to inaccurate pooled results. In this current meta-analysis, we reduced the heterogeneity by including only CHD patients alone. For CHD patients undergoing CABG + the valvular surgery, meta-regression showed no significant effect on our pooled outcomes. In addition, there is another limitation in the previous meta-analysis. Insufficiency of the pooled postoperative endpoints other than MACCEs had impeded meaningful conclusions in cardiac surgical patients. The current research systematically examined the association between OSA and postoperative multiorgan dysfunction, including the parameters of cardiac and cerebral vascular, respiratory and renal function, in CHD patients undergoing elective CABG. The findings of this study might shed new light on optimizing the preoperative risk assessment for postoperative multi-organ dysfunction as well as the peri- and postoperative management of CHD patients undergoing elective CABG.

Previous studies investigating the effects of OSA on postoperative cardiac events among CHD patients following CABG show controversial results. For instance, Uchôa and colleagues ${ }^{14}$ did not find a significant increase in MACCEs (including POAF) among CHD patients undergoing CABG with OSA in the short-term follow-up. On the contrary, Tafelmeier and colleagues ${ }^{13}$ demonstrated sleep-disordered breathing, particularly OSA, is associated with adverse cardiac events after CABG, independent of known confounders. The findings of our study are in accordance with previous studies that found OSA significantly increased the incidence of MACCEs in CHD patients undergoing elective CABG. Notably, the current metaanalysis firstly confirmed OSA was associated with an increased risk of new revascularization. The mechanisms underlying OSA-associated adverse cardiac events among CHD patients undergoing CABG may be correlated to the following aspects: endothelial function, arterial stiffening, as well as systemic inflammation. Our previous meta-analysis of 18 studies aimed to investigate the mechanisms underlying OSA-associated cardiovascular events. ${ }^{1}$ We demonstrated OSA, particularly moderate-severe OSA, was significantly associated with impaired endothelial function (measured by flow mediated dilation and nitroglycerin-induced dilation), increased arterial stiffness (determined by carotid-femoral pulse wave velocity and indicates augmentation index), and elevated serum levels of inflammatory markers (such as high-sensitivity C-reactive protein and Creactive protein), independent of known confounders. ${ }^{1}$ The above factors were often used to predict cardiovascular events in general and morbid populations, especially in CHD patients undergoing CABG. ${ }^{23-25}$ Besides, postoperative troponin T levels, correlated with end-organ damages, suggesting the primary role of an ischemic trigger of end-organ damages. ${ }^{26}$ Although the recent study demonstrated no differences in the myocardial infarction occurrence in CHD patients undergoing CABG with and without OSA, previous studies indicated the potential role of OSAassociated myocardial ischemia in triggering adverse cardiac events (including POAF) among cardiac surgical patients. ${ }^{14,26}$ High-quality randomized controlled trials are still needed to confirm. Finally, limited by the original literature, the current meta-analysis confirmed OSA did not affect the incidence of postoperative CVA or TIA. However, in an observational study of 392 men and women with CHD referred for coronary angiography, Valham et al. demonstrated OSA is an independent predictor for stroke among CHD patients. ${ }^{27}$ Possible factors accounting for OSAassociated stroke among CHD patients include apnea-induced nocturnal cerebral ischemia, hypertension, as well as an increased risk of arteriosclerosis, ${ }^{28-30}$ which are further correlated to stroke. It is worth mentioning that, the independence relationship between sleep-disordered breathing and postoperative heart failure has been confirmed, which contributes to the increased risk of MACCEs. ${ }^{13}$

Although no differences were observed in the occurrence of major pulmonary complications among CHD patients with and without OSA, reintubation and tracheostomy in the OSA group was increased by $243 \%$ and $372 \%$, respectively, compared with the control group. Respiratory failure is a common indication for re-admission to ICU and in-hospital mortality in $\mathrm{CHD}$ patients undergoing CABG. ${ }^{8}$ Both delayed and premature extubation may be correlated to an increased risk of various complications, ${ }^{31,32}$ and the need for reintubation or tracheostomy was viewed as a

potential adverse event after CABG. ${ }^{31-33}$ Previous studies found that requiring reintubation or tracheostomy was associated with organ dysfunction, especially respiratory failure, secondary to physiologic stress, increased mortality, higher hospital costs and longer length of ICU stay. ${ }^{34-36}$ Among CHD patients following CABG, OSA was correlated to a longer intubation time. ${ }^{3,21}$ The current research further confirmed that OSA may contribute to respiratory dysfunction and other adverse events by increasing the incidence of postoperative reintubation and tracheostomy in $\mathrm{CHD}$ patients undergoing CABG.

Currently, no evidence-based studies investigating the effects of OSA on postoperative renal function among CHD patients following CABG. Available reports on the association between OSA and the incidence of AKI after cardiac surgery show conflicting results. In an observational study, 
Wong et al. found that OSA increased the incidence of postoperative AKI and required renal replacement therapy during hospitalization. ${ }^{16}$ In contrast, KAW et al. found that OSA exerted no adverse effects on renal function after cardiac surgery. ${ }^{19}$ We firstly confirmed OSA significantly increased the AKI incidence (by 124\%) compared with the control group. The mechanism underlying the adverse effects of OSA on renal outcomes among cardiac surgical populations still need to be investigated further. An animal model of sleep apnea demonstrated fibrotic changes and inflammatory in the kidney that were attributed to the impacts of intermittent hypoxia. ${ }^{37}$ In addition, previous study also reported nocturnal hypoxemia in OSA patients is correlated to accelerated renal dysfunction, possibly because of increased activity of the renal renin-angiotensin system (RAS) as well as glomerular hypertension. ${ }^{38}$ Moreover, CHD patients following CABG with OSA are also at increased risk of developing preoperative hypertension and diabetes, both of which are closely associated with AKI. ${ }^{39}$ Moreover, in an observational study, Tafelmeier et al. assessed the incidence of AKI after elective CABG in CHD patients without sleep-disordered breathing (SDB), with central sleep apnea (CSA), or with OSA. They demonstrated OSA was correlated to impaired renal function as observed by significantly higher creatinine values and significantly lower glomerular filtration rates than those of patients in the other two groups. ${ }^{13}$

Our results also demonstrated that OSA increased medical resource utilization including length of postoperative hospital stay and ICU stay. An increased length of stay (LOS) in ICU for OSA group suggests that CHD patients with OSA may require greater ventilatory support and longer monitoring after CABG, because of OSA-induced postoperative multi-organ dysfunction. Based on this knowledge, peri- and postoperative management of CHD patients with OSA may be optimized to minimize the rate of postoperative cardio-cerebrovascular, respiratory, as well as renal complications, further reducing the consumption of limited medical resources.

Since OSA may contribute to postoperative multi-organ dysfunction among CHD patients undergoing elective CABG, routine sleep apnea screening before CABG need to be conducted for a diagnosis to be firmly established and to determine the type and severity of OSA that will dictate treatment alternatives. PSG is the gold standard for confirming the presence of OSA. ${ }^{3}$ However, PSG is costly and time-consuming. ${ }^{26}$ This justified the development of ambulatory abbreviated cardiorespiratory recording techniques and establishment of guidelines for the use of these devices. ${ }^{27}$ In addition, sleep apnea treatment initiation in the peri-operative phase is also recommended. CPAP therapy is the most effective therapy for OSA, and perioperative CPAP use may optimize the condition of surgical patients with OSA. ${ }^{6}$

There are some limitations to the findings of this current research since the absence of randomized controlled trials. Selection bias and treatment bias, inherent to the observational studies, may exist. Moreover, in the current study, heterogeneity was reduced by including only CHD patients alone. Limited by the original literature, we also included CHD patients undergoing CABG + the valvular surgery. Although meta-regression showed the valvular surgery did not affect on our pooled outcomes, high-quality randomized controlled trials focusing on $\mathrm{CHD}$ patients undergoing isolated CABG are still needed in the future. In addition, since the sample size of each original studies limitations, currently we cannot further address the effects of mild, moderate as well as severe OSA on multiple organ dysfunction, respectively, in CHD patients undergoing CABG.

\section{Conclusions}

In conclusion, the current evidence-based research demonstrated OSA may contribute to postoperative multi-organ dysfunction among CHD patients undergoing elective CABG by increasing the incidence of MACCEs, especially new revascularization (including CABG and PCI), as well as respiratory, and renal complications. Furthermore, our results also demonstrated that OSA increased medical resource utilization including length of postoperative hospital stay and ICU stay. Based on this knowledge, peri- and postoperative management of CHD patients with OSA may be optimized to minimize the rate of postoperative parameters of multi-organ dysfunction, further reducing the consumption of limited medical resources.

\section{Abbreviations}

\section{CABG}

Coronary Artery Bypass Grafting; OSA:Obstructive Sleep Apnea; SE:Standard Error; OR:Odds Ratio; SMD:Standardized Mean Difference; Cl:Confidence Interval; MACCEs:Major Adverse Cardiovascular and Cerebral Events; MI:Myocardial infarction; TIA:Transient Ischemic Attack; CVA:Cerebral Vascular Accident; PCl:Percutaneous Coronary Intervention; AKI:Acute Kidney Injury; CHD, Coronary Heart Disease; POAF:Postoperative Atrial Fibrillation; STS, Society of Thoracic Surgeons; ARDS:Acute Respiratory Distress Syndrome.

\section{Declarations}

\section{Ethical Approval and Consent to participate}

The study protocol was reviewed and approved by the ethics committee of

all participant institutes in the Beijing An Zhen Hospital Capital Medical University 
Not applicable.

\section{Availability of supporting data}

No data were used to support this study.

\section{Competing interests}

The authors declare that they have no competing interests.

\section{Funding}

This study was supported by the Foundation of Beijing Anzhen Hospital, Capital Medical University (No. 2016Z01), the National Natural Science Foundation of China (Grant No. 81900098), the "Beijing Municipal Administration of Hospitals" Youth Plan (Code: QML20190601), the talents support program of Organization Department of Beijing Municipal Committee (No. 2017000021469G221), the program of the Beijing Municipal Administration of Hospitals (No. XMLX201822).

\section{Authors' contributions}

Dr. Jiayang Wang and Prof. Yongxiang Wei designed the current study, and drafted the manuscript. Dr. Wenyuan Yu and Dr. Xinxin Wang independently extracted the information from the eligible studies. Besides, Dr. Kui Zhang performed the statistical analysis. Dr. Jiayang Wang participated in the quality assessment.

\section{Acknowledgements}

We thank Dr Gui Su for editing and proofreading the manuscript. The statistical analysis was reviewed by Dr Longfei Wang.

\section{References}

1.

Wang J, Yu W, Gao M, Zhang F, Gu C, Yu Y, Wei Y. Impact of Obstructive Sleep Apnea Syndrome on Endothelial Function, Arterial Stiffening, and Serum Inflammatory Markers: An Updated Meta-analysis and Metaregression of 18 Studies. J Am Heart Assoc. 2015;4.

2.

Senaratna CV, Perret JL, Lodge CJ, Lowe AJ, Campbell BE, Matheson MC, Hamilton GS, Dharmage SC. Prevalence of obstructive sleep apnea in the general population: A systematic review. Sleep Med Rev. 2017;34:70-81.

3.

Foldvary-Schaefer N, Kaw R, Collop N, Andrews ND, Bena J, Wang L, Stierer T, Gillinov M, Tarler M, Kayyali H. Prevalence of Undetected Sleep Apnea in Patients Undergoing Cardiovascular Surgery and Impact on Postoperative Outcomes. J Clin Sleep Med. 2015;11:1083-9.

4.

Qaddoura A, Kabali C, Drew D, van Oosten EM, Michael KA, Redfearn DP, Simpson CS, Baranchuk A. Obstructive Sleep Apnea as a Predictor of Atrial Fibrillation After Coronary Artery Bypass Grafting: A Systematic Review and Meta-analysis. Can J Cardiol. 2014;30:1516-22.

5.

Chen A, Chen Y. Obstructive Sleep Apnea as a Predictor of Atrial Fibrillation After Coronary Artery Bypass Grafting. Canadian Journal of Cardiology. 2015;31.

6.

Nagappa M, Ho G, Patra J, Wong J, Singh M, Kaw R, Cheng D, Chung F. Postoperative Outcomes in Obstructive Sleep Apnea Patients Undergoing Cardiac Surgery: A Systematic Review and Meta-analysis of Comparative Studies. Anesth Analg. 2017;125:2030-7. 
Ding N, Ni B-Q, Wang H, Zhang S-J, Zhang X-L. Obstructive Sleep Apnea: A Risk Factor of Cardiac Valve Replacement Surgery. J Clin Sleep Med. 2016;12:1573-5.

8.

Feng TR, White RS, Ma X, Askin G, Pryor KO. The effect of obstructive sleep apnea on readmissions and atrial fibrillation after cardiac surgery. J Clin Anesth. 2019;56:17-23.

9.

Moher D, Liberati A, Tetzlaff J, Altman DG, Group P. Preferred reporting items for systematic reviews and meta-analyses: the PRISMA statement. BMJ. 2009;339:b2535.

10.

Raza S, Sabik JF 3rd, Ainkaran P, Blackstone EH. Coronary artery bypass grafting in diabetics: A growing health care cost crisis. J Thorac Cardiovasc Surg. 2015;150:304-2 e2.

11.

Mungan U, Ozeke O, Mavioglu L, Ertan C, Karaca IO, Keskin G, Kokcu Z, Selimoglu Y, Demir AD, Ozatik MA. The role of the preoperative screening of sleep apnoea by Berlin Questionnaire and Epworth Sleepiness Scale for postoperative atrial fibrillation. Heart Lung Circ. 2013;22:38-42.

12.

Patel SV, Gill H, Shahi D, Rajabalan A, Patel P, Sonani R, Bhatt P, Rodriguez RD, Bautista M, Deshmukh A, Gonzalez JV, Patel S. High risk for obstructive sleep apnea hypopnea syndrome predicts new onset atrial fibrillation after cardiac surgery: a retrospective analysis. Sleep Breath. 2018;22:1117-24.

13.

Tafelmeier M, Weizenegger T, Ripfel S, Fauser M, Floerchinger B, Camboni D, Zausig Y, Wittmann S, Drzymalski MA, Zeman F, Schmid C, Maier LS, Wagner S, Arzt M. Postoperative complications after elective coronary artery bypass grafting surgery in patients with sleep-disordered breathing. Clin Res Cardiol. 2018;107:1148-59.

14.

Uchoa CHG, Danzi-Soares NJ, Nunes FS, de Souza AAL, Nerbass FB, Pedrosa RP, Cesar LAM, Lorenzi-Filho G, Drager LF. Impact of OSA on cardiovascular events after coronary artery bypass surgery. Chest. 2015;147:1352-60.

15.

van Oosten EM, Hamilton A, Petsikas D, Payne D, Redfearn DP, Zhang S, Hopman WM, Baranchuk A. Effect of preoperative obstructive sleep apnea on the frequency of atrial fibrillation after coronary artery bypass grafting. Am J Cardiol. 2014;113:919-23.

16.

Wong JK, Maxwell BG, Kushida CA, Sainani KL, Lobato RL, Woo YJ, Pearl RG. Obstructive Sleep Apnea Is an Independent Predictor of Postoperative Atrial Fibrillation in Cardiac Surgery. J Cardiothorac Vasc Anesth. 2015;29:1140-7.

17.

Zhao LP, Kofidis T, Lim TW, Chan SP, Ong TH, Tan HC, Lee CH. Sleep apnea is associated with new-onset atrial fibrillation after coronary artery bypass grafting. J Crit Care. 2015;30:1418 e1-5.

18.

Amra B, Niknam N, Sadeghi MM, Rabbani M, Fietze I, Penzel T. Obstructive sleep apnea and postoperative complications in patients undergoing coronary artery bypass graft surgery: a need for preventive strategies. Int J Prev Med. 2014;5:1446-51.

19.

Kaw R, Golish J, Ghamande S, Burgess R, Foldvary N, Walker E. Incremental risk of obstructive sleep apnea on cardiac surgical outcomes. J Cardiovasc Surg (Torino). 2006;47:683-9.

20.

Mooe T, Gullsby S, Rabben T, Eriksson P. Sleep-disordered breathing: a novel predictor of atrial fibrillation after coronary artery bypass surgery. Coron Artery Dis. 1996;7:475-8.

21.

Bhama JK, Spagnolo S, Alexander EP, Greenberg M, Trachiotis GD. Coronary revascularization in patients with obstructive sleep apnea syndrome. Heart Surg Forum. 2006;9:E813-7.

22.

S S. Prevalence of obstructive sleep apnea in patients undergoing coronary artery bypass graft surgery (CABG). A pilot study. J Sleep Disord Treat Care. 2012:1-5.

23.

Wang J, Yu W, Gao M, Zhang F, Li Q, Gu C, Yu Y, Wei Y. Continuous positive airway pressure treatment reduces cardiovascular death and non-fatal cardiovascular events in patients with obstructive sleep apnea: A meta-analysis of 11 studies. Int J Cardiol. 2015;191:128-31.

24.

Vlachantoni IT, Dikaiakou E, Antonopoulos CN, Stefanadis C, Daskalopoulou SS, Petridou ET. Effects of continuous positive airway pressure (CPAP) treatment for obstructive sleep apnea in arterial stiffness: a meta-analysis. Sleep Med Rev. 2013;17:19-28. 
25.

Drager LF, Togeiro SM, Polotsky VY, Lorenzi-Filho G. Obstructive sleep apnea: a cardiometabolic risk in obesity and the metabolic syndrome. J Am Coll Cardiol. 2013;62:569-76.

26.

Narducci ML, Pelargonio G, Rio T, Leo M, Di Monaco A, Musaico F, Pazzano V, Trotta F, Liuzzo G, Severino A, Biasucci LM, Scapigliati A, Glieca F, Cavaliere F, Rebuzzi AG, Massetti M, Crea F. Predictors of postoperative atrial fibrillation in patients with coronary artery disease undergoing cardiopulmonary bypass: a possible role for myocardial ischemia and atrial inflammation. J Cardiothorac Vasc Anesth. 2014;28:512-9.

27.

Valham F, Mooe T, Rabben T, Stenlund H, Wiklund U, Franklin KA. Increased risk of stroke in patients with coronary artery disease and sleep apnea: a 10-year follow-up. Circulation. 2008;118:955-60.

28.

Peppard PE, Young T, Palta M, Skatrud J. Prospective study of the association between sleep-disordered breathing and hypertension. N Engl J Med. 2000;342:1378-84.

29.

Balfors EM, Franklin KA. Impairment of cerebral perfusion during obstructive sleep apneas. Am J Respir Crit Care Med. 1994;150:1587-91.

30.

Shahar E, Whitney CW, Redline S, Lee ET, Newman AB, Nieto FJ, O'Connor GT, Boland LL, Schwartz JE, Samet JM. Sleep-disordered breathing and cardiovascular disease: cross-sectional results of the Sleep Heart Health Study. Am J Respir Crit Care Med. 2001;163:19-25.

31.

Steidl C, Boesel J, Suntrup-Krueger S, Schoenenberger S, Al-Suwaidan F, Warnecke T, Minnerup J, Dziewas R. Tracheostomy, Extubation, Reintubation: Airway Management Decisions in Intubated Stroke Patients. Cerebrovasc Dis. 2017;44:1-9.

32.

Peterson GN, Domino KB, Caplan RA, Posner KL, Lee LA, Cheney FW. Management of the difficult airway: a closed claims analysis. Anesthesiology. 2005;103:33-9.

33.

Miltiades AN, Gershengorn HB, Hua M, Kramer AA, Li G, Wunsch H. Cumulative Probability and Time to Reintubation in U.S. ICUs. Crit Care Med. 2017;45:835-42.

34.

Thille AW, Harrois A, Schortgen F, Brun-Buisson C, Brochard L. Outcomes of extubation failure in medical intensive care unit patients. Crit Care Med. 2011;39:2612-8.

35.

Epstein SK, Ciubotaru RL. Independent effects of etiology of failure and time to reintubation on outcome for patients failing extubation. Am J Respir Crit Care Med. 1998;158:489-93.

36.

Thille AW, Richard JC, Brochard L. The decision to extubate in the intensive care unit. Am J Respir Crit Care Med. 2013;187:1294-302.

37.

Sun W, Yin X, Wang Y, Tan Y, Cai L, Wang B, Cai J, Fu Y. Intermittent hypoxia-induced renal antioxidants and oxidative damage in male mice: hormetic dose response. Dose Response. 2012;11:385-400.

38.

Ahmed SB, Ronksley PE, Hemmelgarn BR, Tsai WH, Manns BJ, Tonelli M, Klarenbach SW, Chin R, Clement FM, Hanly PJ. Nocturnal hypoxia and loss of kidney function. PLoS One. 2011;6:e19029.

39.

Marin JM, Agusti A, Villar I, Forner M, Nieto D, Carrizo SJ, Barbe F, Vicente E, Wei Y, Nieto FJ, Jelic S. Association between treated and untreated obstructive sleep apnea and risk of hypertension. JAMA. 2012;307:2169-76.

\section{Figures}




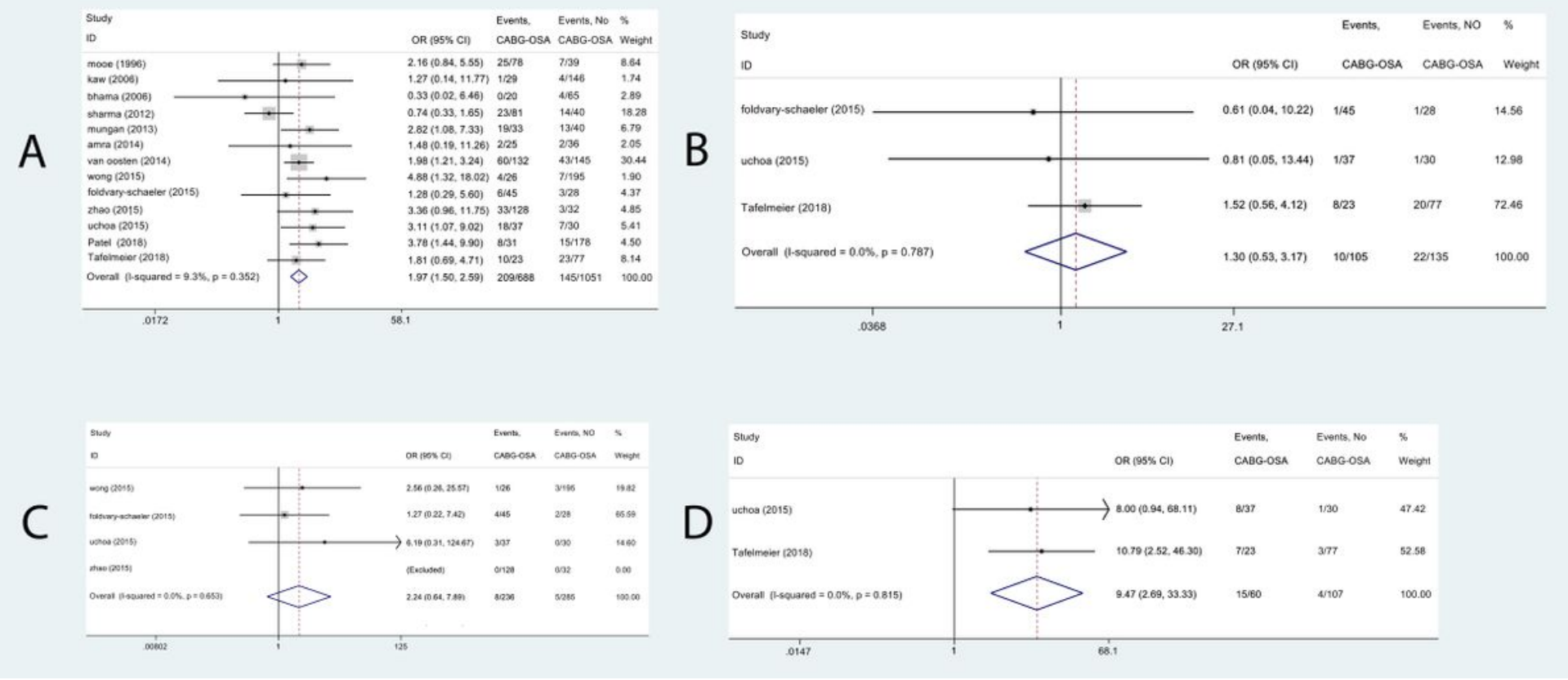

\section{Figure 1}

The impact of OSA on postoperative cardiac and cerebrovascular parameters in CHD patients following elective CABG. Cardiac and cerebrovascular parameters: 1A, MACCEs; 1B, Ml; 1C, CVA or TIA; 1D, New revascularization, including CABG and PCI. OSA, obstructive sleep apnea; $\mathrm{CHD}$, coronary heart disease; $\mathrm{CABG}$, coronary artery bypass grafting; MACCEs, major adverse cardiac and cerebrovascular events; $\mathrm{Ml}$, myocardial infarction; CVA, cerebral vascular accident; TIA, transient ischemic attack; PCl, percutaneous coronary intervention; OR, odds risk; Cl, confidence interval.

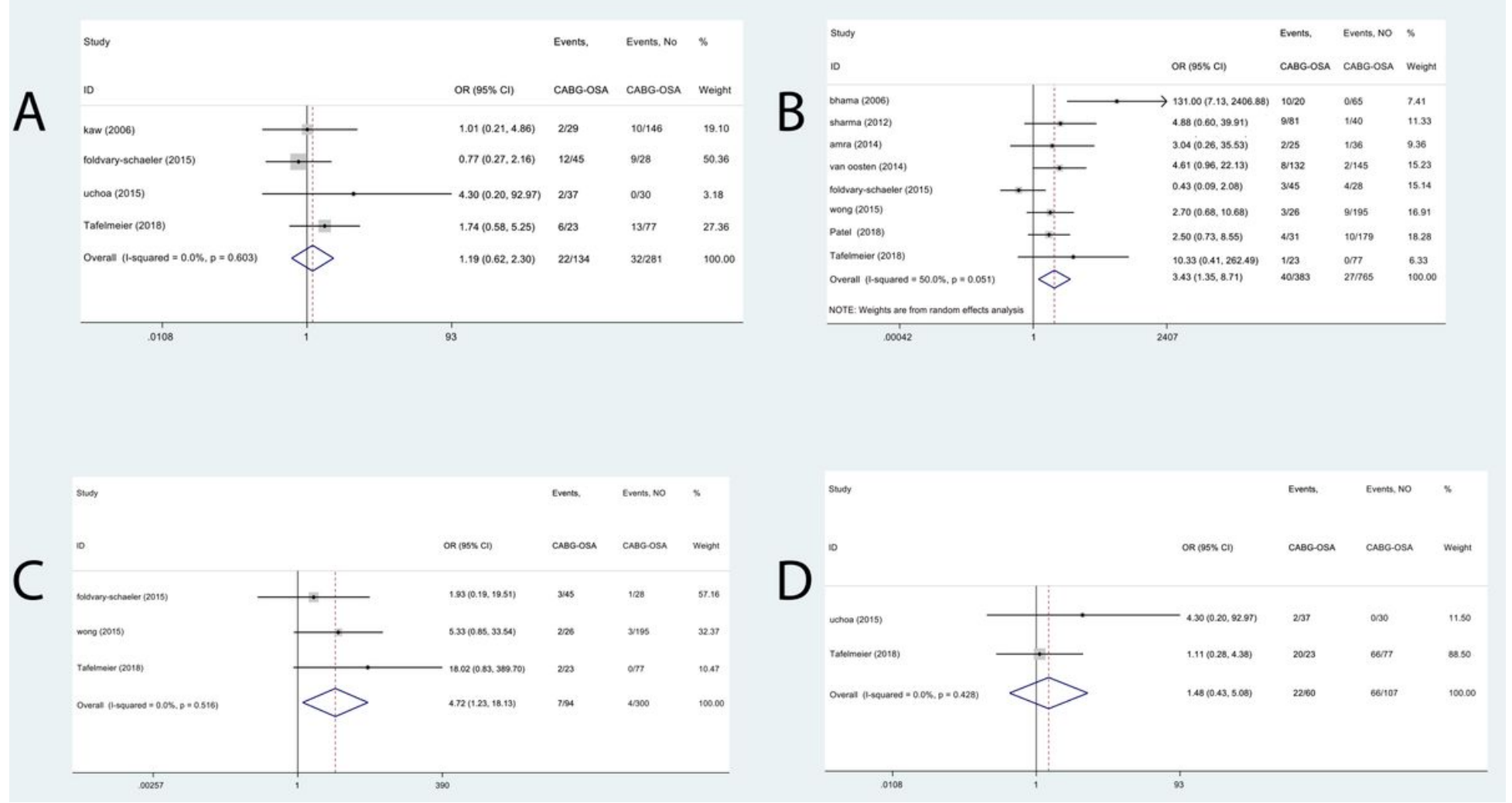

Figure 2

The impact of OSA on postoperative respiratory parameters in CHD patients following elective CABG. Respiratory parameters: 2A, Postoperative major pulmonary complications; 2B, Reintubation; 2C, Tracheostomy; 2D, Pulmonary edema. OSA, obstructive sleep apnea; CHD, coronary heart 


\begin{tabular}{|c|c|c|c|c|}
\hline Study & & Events, & Events, No & $\%$ \\
\hline ID & OR $(95 \% \mathrm{Cl})$ & CABG-OSA & CABG-OSA & Weight \\
\hline kaw (2006) & $1.27(0.14,11.77)$ & $1 / 29$ & $4 / 146$ & 14.49 \\
\hline wong (2015) & $\rightarrow 6.23(1.31,29.59)$ & $3 / 26$ & $4 / 195$ & 9.43 \\
\hline zhao (2015) & $1.29(0.06,27.64)$ & $2 / 127$ & $0 / 32$ & 8.83 \\
\hline Tafelmeier (2018) & $2.02(0.79,5.19)$ & $12 / 23$ & $27 / 77$ & 67.25 \\
\hline Overall (I-squared $=0.0 \%, p=0.557)$ & $2.24(1.07,4.72)$ & $18 / 205$ & $35 / 450$ & 100.00 \\
\hline $\begin{array}{c}1 \\
.0338\end{array}$ & $\begin{array}{c}1 \\
29.6\end{array}$ & & & \\
\hline
\end{tabular}

Figure 3

The impact of OSA on postoperative AKI in CHD patients following elective CABG. OSA, obstructive sleep apnea; CHD, coronary heart disease; $\mathrm{CABG}$, coronary artery bypass grafting; $\mathrm{AKI}$, Acute kidney injury; OR, odds risk; $\mathrm{Cl}$, confidence interval.

\section{Supplementary Files}

This is a list of supplementary files associated with this preprint. Click to download.

- FIGii.jpg

- figi.JPG 